Jurnal Keperawatan Padjadjaran

ISSN 2338-5324 (print)

ISSN 2442-7276 (online)

Online di http://jkp.fkep.unpad.ac.id

DOI : $10.24198 / \mathrm{jkp}$

\title{
Nurses' Life Experiences as Persons in Charge of Mental Health Programs in Community Health Centers
}

\author{
Habsyah S Agustina, Suryani, Efri Widianti \\ Faculty of Nursing Universitas Padjadjaran, Bandung, Indonesia \\ Corresponding email: habsyah.rida@gmail.com
}

Submitted: 21-01-2019 Accepted: 19-08-2019 Published: 19-08-2019

\begin{abstract}
At present, Mental health issue becomes one of the main issues in public health issues in community health centers such as the complexity of the issues in the work of nurses in charge of mental health programs. The purpose of this study was to explore the nurse's life experience as a person in charge of mental health programs in community health centers. The research design used descriptive phenomenology. The study population was nurses responsible for mental health programs in community health centers, experienced in taking care of people with mental disorders for at least six months, and at least had a Diploma in nursing. The number of participants was determined by purposive sampling technique to obtain seven participants. The experiences of nurses were explored through in-depth interviews, and data were analyzed using the Colaizzi method of analysis. Study results found five themes: (1) feeling burdened by the responsibility for mental health programs; (2) feeling insecure due to the lack of knowledge; (3) feeling there were many barriers and constraints in caring for people with mental illness during the recovery period; (4) hoping to collaborate with relevant government institutions; and (5) being more grateful for caring for people with mental illness. In conclusion, nurses are responsible for mental health programs even though they feel burdened with their workload, but they can still do their jobs because they always have hope and are grateful. The nurses are trained nurses and can collaborate with relevant government institutions.
\end{abstract}

Keywords: Mental illness, nurse's experience, phenomenology study. 
Habsyah S Agustina: Nurses' Life Experiences as Persons In Charge of Mental Health Programs

\section{Introduction}

The mental health program remains a neglected problem, as evidenced by the small number of funds allocated by the government; therefore, it also lacks attention (Russell, 2010). This condition is reinforced by WHO (2005), which claims that middle and lowincome countries get a smaller allocation of funds for mental health programs. The lack of public and municipal concerns regarding mental health issues make an impact on its implementation, irregular monitoring and evaluation, and government campaigns tending to focus on physical illness (Abdulmalik, Kola, \& Gureje, 2016).

The results of preliminary studies conducted by researchers through interviews with nurses in charge of mental health programs, in one of the community health centers in Cimahi, namely a nurse with the initial D found the phenomenon that the role of nurses in charge of mental health programs is only recording data and reporting the number of patients visiting community health center and made home visits.

Nurse D said that during her experience, she was confused about the coordination flow when dealing with people with mental illness in the neighborhood. According to her, dealing with people with mental illness required communication with regency and social workers. Besides, the community health center did not provide particular space for consultation and special days for mental health examinations.

The researcher's observation results confirmed this phenomenon during field experience at community health centers. Nurse D was not only responsible for mental health programs but also handled the immunization program at the Maternal and Child Health Center (Posyandu). She recorded data of visiting patients to the community health center and home visitors. However, schedule adjustments, a particular room for a check-up, and a consultation room for mental health service were unavailable at the moment.

Based on the policy regulation of the Minister of Health Republic of Indonesia
No. 406 (2009), community mental health is an approach to people-based mental health service. The people are involved actively. This service includes aspects of promotion, prevention, curative, and rehabilitation. Currently, mental health service has changed fundamentally from a closed treatment to extensive treatment and the handling of the mental problem from clinical-individual to productive-social.

The coverage of mental health service in community health center of Cimahi City reaches $1.58 \%$, according to the Health Agency of Cimahi City in 2017. This number is far from the $100 \%$ target. In the same year, the number of people with mental illness in 13 community health centers in Cimahi reaches 2.139 people, while those doing check-up and treatment in the same locations reach 3043 . The total of patients visit with a mental problem in 2017 reaches 327.344 , and the number of patients with an acute mental problem is 492 .

Community mental health services require quality human resources. At present, their role is passive and focuses only on people with mental illness. Promotional efforts and prevention in dealing with psychological problems are not holistic because nurses only wait for patients to come and then refer them to the Mental Institution (Suryani, 2012).

Mental health nurses can assist in the recovery of mentally challenged individuals. Suryani (2013) points out that this effort can recover patients by reducing the number of possible recurrences in recovered patients. Also, that recovery was a journey--a lengthy process faced by an individual with chronic mental problems, so that that person can fight for a better life, despite his/her limitations.

In its implementation, mental health nurses have a vital role in the recovery process of people with mental illness in society. Therefore, adequate knowledge about being in charge of mental health programs is more than necessary. What they need, the problems that will arise, and how they solve the problem. This research aimed to explore the experiences of Indonesian nurses as the person in charge of mental health programs in community health centers. 
Habsyah S Agustina: Nurses' Life Experiences as Persons In Charge of Mental Health Programs

\section{Method}

This study used the qualitative method with a phenomenological approach to gain an understanding of phenomena in social-natural contexts by promoting the process of deep interaction between researchers and scientific aspects (Polit \& Beck, 2005). However, Patton (2005) states that qualitative research studies real-world settings inductively, producing specific patterns and themes.

Phenomenology was proposed by Husserl (Giorgi \& Giorgi, 2008). It has human phenomena as its background and focuses on explaining life experiences and constructing meaning (Streubert \& Carpenter, 2007). In this study, phenomenology aimed to get actual meaning through broad involvement of reality (Laverty, 2003 in Lopez \& Willis, 2004).

The aim of phenomenology, strengthened by Suryani, Welch, and Cox (2016), is to gain subjective understanding meaning from daily experiences in the language of the individual. Therefore, this research applied phenomenology to reveal the lived experience of a person in charge of mental health in community health centers.

This research conducted from May to August 2018 at seven community health centers in Cimahi city and received ethical approval from the Faculty of Medicine in the field of Health Studies at Padjadjaran University in Bandung with number 571/ UN6.KEP / EC / 2018. The study involved seven participants and conducted in-depth interview. Criteria for participants were as follows; the person was in charge of the mental health program in the community health center, experienced in handling people with mental illness for at least six months, and having a Nursing diploma.

The interviews were conducted for 60 to 90 minutes while taking a break or relaxing at the community health center where the participants worked. Previously, they were informed about the purpose and use of this research. The main question raised by the researchers was "In your opinion, what do you think is required to be in charge of the mental health program during the recovery process of individuals with mental illness in the community health center?" This question was followed by exploring issues to anticipate if the researcher faced obstacles or unanswered questions. The researcher also applied focusing techniques when participants responded aggressively.

This study applied the Colaizzi method for data analysis indicating validation is the result of the participant, meaning that whatever the outcome, it must be in line with the interviewee's intention. According to Colaizzi (1978) in Polit and Beck (2008), and Suryani, Welch, and Cox (2016), there are seven phases to get the essence of each transcription namely, extract relevant statements, formulate meaning from significant statements, organize definitions to be formulated into a series of themes, write full descriptions of the phenomenon, describe the basic structure of the phenomenon, and carry out checking.

During data collecting and analyzing, the researcher applied the bracketing principle to get subjectivity value or neutrality by casting aside understanding and stigma about the observed phenomenon (Giorgi, 2011). The researcher also observed the basic principles of ethics during the time of research, including benefits, autonomy, anonymity, and justice (Polit and Beck, 2010).

\section{Results}

The findings of the study showed that the life experience of participants in seven community health centers as the person in charge of mental health programs lasted from 1 to 9 years. All participants were female and Muslims. The age range of participants was from 31 to 41 years old. All participants had pursued the education level of D3 of nursing, and one participant completed the Bachelor of Nursing. The working period for all participants in the community health center lasted about 1 to 13 years. All the participants were married.

Study results found five themes including feeling burdened by responsibility for the mental health program, feeling insecure due to the lack of knowledge, feeling many obstacles and constraints while caring for people with mental illness during the recovery period, hoping to collaborate with 
the relevant government institutions, and being more grateful for caring for people with mental illness (Table 1).

In the first theme, all participants revealed that they felt burdened in handling people with mental illness during the recovery process. Three participants said that they were exhausted and irritated when handling them. All these showed that caring for people with mental illness was not an easy task. Participant 4 also had a similar view:

"... The burden is unbearable. Expectations for my workload are too hard to do alone. "(P4.16)

Based on the analysis results and transcripts of participants, the researcher found it essential to raise this theme, not only because all participants have expressed similar opinions but also because it is in line with the purpose of this research, namely to find new insights. Although previous studies have discussed the heavy workload, none has considered the heavy workload faced by the person in charge of the mental health program in handling people with mental illness during recovery in the community health center.

In the second theme, the participants felt insecure due to the lack of knowledge. Two participants revealed that they were not confident when doing assignments. However, another participant told something different, as he felt confident when completing the task because he had participated in the training. Besides, three other participants revealed that they did not know anything during their duties. Four other participants expressed fear during the task, and two participants expressed confusion in carrying out assignments.

The study result showed that the lack of experience of the participants in addressing people with mental illness, family, and society was due to the lack of knowledge about roles and responsibilities while implementing community mental health programs so that participants felt fearful and confused.

Based on the analysis result and repeated readings of participant transcripts, this theme was a new insight with characteristics. If a person lacked knowledge in performing its duties, it would appear as a sense of lack of confidence, fear, and confusion so that it can hinder the implementation of mental health programs. As claimed by participant 2:
"I am almost not confident. I will get a company for a home visit. Otherwise, I am stranded." (P2.20).

However, participant 5 gave a distinct comment because he attended the training. The following was the participant's statement: "Early detection training makes me confident. It improves my performance." (P5.61)

In the third theme, the focus was on obstacles in handling the recovery of people with mental illness. There were three subthemes in this theme, namely the obstacles in the implementation of references and evacuation of patients, unavailable time and experience handling people with mental illness, and obstacles on the facilities, human resources, and fund. There were three participants with the protagonist view, which was due to the low substance of mental health nurses and the feeling of fear while handling acute patients during the evacuation.

Four participants revealed the lack of a nurse's time and experiences while handling people with mental illness. Another reason was that the workload was too heavy so that they could not explore their work more deeply. This condition became the nurse's obstacle while performing their duties in mental health programs.

Five participants complained about the infrastructure, facilities, human resource, and funds. This was because there were no training programs for patients to get their own money, lack of nurses for mental health in community mental health centers, no male nurses at work, lack of referral hospitals with inpatients, no rooms and special times for people for mental illness counseling, and lack of funds to carry out activities. Participants 1, 2, 3, and seven said as follows:

"Our time collides/clash. We always lack focus. We have to do one program while doing another here....". (P1.27)

"We cannot explore more deeply; then it becomes difficult. Maybe because we lack experience "(P2.18)

"We do not have any program or training whatsoever that can make our patients make a living on their own" (P3.44)

"Evacuating mentally disabled people? Who wants to fund it? "( $\mathrm{P} 7.83)$

In the fourth theme, the focus was on the hope of having good cooperation among 
relevant stakeholders to handle people with mental illness. There were three sub-themes as follows: collaboration with patients and family in the process of patient's recovery, the government's institution regarding training and cooperation to handle recovery of people with mental illness, and hoping that the society and public figures support the entire process.

The first sub-theme: expect to work with patients and their families. Four participants expressed their concern so that patients would take medication regularly and get active again. As one of them claimed:

"Of course, I have my hopes. He must be useful for his family and neighbors. He must be independent and productive, even though he still consumes drugs". (P1.22).

The second sub-theme: government institutions organize training programs and good cooperation. One of the participants hoped that health institutions could conduct training programs on mental health.
The training required a follow-up after conducting early detection, counseling, training to improve nurses' skills to deal with people with mental illness, training trainers, environment and hamlets about mental health, and empowering people with mental illness. One participant exclaimed:

"We must carry out holistic socialization, starting from training, workshops, and education" (P3.74)

The third sub-theme: the community and community leaders must support the recovery process of people with mental illness as told by all participants. They hoped people would pay more attention to people with mental illness. Participant 4 said:

"We hope that nothing is hidden. There are still people out there who think that mental illness is a kind of curse." (P4.26)

In the fifth theme, the participants felt grateful while caring for mental health patients. Two participants were grateful while caring for people with mental illness. After

Table 1 Schemes of Research Themes: Nurses' Life Experiences as Persons in Charge of Mental Health Programs in Community Health Centers

\begin{tabular}{|c|c|c|c|c|}
\hline 1st Theme & 2nd Theme & 3rd Theme & 4th Theme & 5th Theme \\
\hline \multirow[t]{5}{*}{$\begin{array}{l}\text { Feeling burdened } \\
\text { by responsibility } \\
\text { for mental health } \\
\text { programs }\end{array}$} & $\begin{array}{l}\text { Feeling insecure } \\
\text { due to lack of } \\
\text { knowledge. }\end{array}$ & $\begin{array}{l}\text { Feeling there were } \\
\text { many obstacles and } \\
\text { constraints in caring } \\
\text { for individuals } \\
\text { with mental illness } \\
\text { during the recovery } \\
\text { period. }\end{array}$ & $\begin{array}{l}\text { Hoping to } \\
\text { collaborate with } \\
\text { relevant government } \\
\text { institutions. }\end{array}$ & $\begin{array}{l}\text { Being more grateful } \\
\text { for caring for people } \\
\text { with mental } \\
\text { illness }\end{array}$ \\
\hline & & sub-themes: & sub-themes: & \\
\hline & & $\begin{array}{l}\text { 1. Barriers to } \\
\text { Implementation of } \\
\text { Referral and Patient } \\
\text { Evacuation }\end{array}$ & $\begin{array}{l}\text { 1. Hope can } \\
\text { cooperate with } \\
\text { patients and families } \\
\text { in the recovery } \\
\text { process of people } \\
\text { with mental illness }\end{array}$ & \\
\hline & & $\begin{array}{l}\text { 2. Lack of time and } \\
\text { experience of nurses } \\
\text { dealing with people } \\
\text { with mental illness } \\
\text { in the recovery } \\
\text { period }\end{array}$ & $\begin{array}{l}\text { 2. Related } \\
\text { government } \\
\text { institutions can } \\
\text { conduct training } \\
\text { and cooperation in } \\
\text { dealing with people } \\
\text { with mental illness } \\
\text { in the recovery } \\
\text { period }\end{array}$ & \\
\hline & & $\begin{array}{l}\text { 3. Constraints } \\
\text { on facilities, } \\
\text { infrastructure, } \\
\text { human resources } \\
\text { (HR), and funding } \\
\text { assistance }\end{array}$ & $\begin{array}{l}\text { 3. Communities and } \\
\text { community leaders } \\
\text { can support the } \\
\text { recovery process for } \\
\text { people with mental } \\
\text { illness }\end{array}$ & \\
\hline
\end{tabular}


the in-depth analysis and frequent reading of scripts, this theme seemed quite vital as it showed new insights, though few participants said so. It was very close to religion in Indonesia, and the participant's religious characteristics, of whom the majority are Muslim.

When caring for people with mental illness, participants felt grateful for having better conditions and did not get the obstacles of life like them. Quoted thoroughly: "We are grateful. Thank God that I am healthy, and not being "tested" like those people with mental illness." (P1.40).

\section{Discussion}

\section{Feeling burdened by the responsibility for mental health programs}

The study result showed that during the assignment, mental health community nurses had a difficult task since they must check patients through many programs (Marchira, 2011). Carayon and Gurses (2008) state that not only community nurses experience heavy workloads but also nurses in hospitals. Nurses have heavy workloads due to four main reasons: (1) increased demand for nurses, (2) inadequate supply of nurses, (3) reduced staffing and increased over time and (4) reducing inpatient length of stay (Carayon \& Gurses, 2008).

The nurses' heavy workloads can have an impact on themselves. Edwards, Burnard, Coyle, Fothergill, and Hannigan (2008) confirms that many mental health nurses face stress and fatigue due to the increasing workload, lack of human and financial resources, and increased administrative work, time management, misguided references, do not have enough time for independent learning, and general working conditions.

Besides, the heavy workload may impact on nurses' job satisfaction, and the result can contribute to service quality and lack of human nursing resources (Duffield \& O'Brien, 2013). Other impacts also affect patients, as confirmed by Lang, Hodge, Olson, Romano, and Kravitz (2004).

\section{Feeling insecure due to lack of knowledge}

The healthcare staff in community health centers requires adequate knowledge and skill. Lack of both will impact to the quality service. It is one of their responsibilities to empower patients so that they can tackle problems on their own and maintain a healthy condition (Pinilih, Astuti, \& Amin, 2015).

In Gale and Lucette (2011), we found that the gap in the perception of capability and confidence of nurses in recovery-oriented practices are taught academically. Therefore, nursing education should focus more on the model of recovery and its implementation for care delivery. The preparation of adequate resource must be conducted, so that the recovery process can be performed holistically, especially in mental health services. Thus, there will be a healthy society both physically and emotionally (Pinilih, Astuti \& Amin, 2015).

Improving nurses' knowledge is essential by attending training on community mental health. This is confirmed by Bangun and Soewadi (2014) that there are significant differences before and after training in mental health programs on knowledge of nurses $p=0,000(p<0.05)$. Besides training, the main requirement for being responsible for mental health programs is to have competence in education. Levin, Hennessy, and Petrilia (2010) claim that the education background of the community mental health nurse must be at least a bachelor's degree, with a specialization in psychology. This is to ensure that the nurses can foster, educate, and advise individuals with mental illness about mental health. However, in this study, the educational characteristic of all participants was a Nursing Diploma. Therefore, the Indonesian government can assign a person in charge with an undergraduate degree as the minimum requirement.

\section{Feeling many obstacles and constraints in caring for people with mental illness during the recovery period \\ Mental health resources and facilities} are still scarce, and it is not possible if the government provides nurses and mental health nurses in a relatively short time. Therefore, one thing to be done is to attend mental health training for healthcare staff in primer services (Marchira, 2011). There are two skills for teaching mental health nurses, 
especially on mental and psychosocial health (Ignacio, 2000).

Based on study results, the main obstacle during referring and evacuating patients was the lack of focus when evacuating, while referring that it clashed with other tasks, besides that they were afraid of dealing with male patients. The role of mental health nurses is as a placement co-coordinator, nurses referring clients to their place can accept additional help like shelters, rehabilitation, and long-term life treatment (Huang, Ma, Shih, \& Li, 2008).

Factors that can hinder the recovery process of people with mental illness are the people's negative stigma, inadequate human resources, negative attitudes towards patients, lack of confidence, failure to take and resolve problems in critical situations, poor listening skills, symptom-based treatment and not need-based treatment (Happell, 2008).

The negative perception causes many obstacles and problems faced by the community health nurse in handling people with mental illness, namely poor time management and less focus on doing the program and feeling fear of dealing with people with mental illness, and lack of handling experiences. The success of handling people with mental illness during the recovery process can be carried out by refreshing about the role of mental health. Assignment of the nurse' responsibilities in community mental health and people with mental illness recovery toward all nurses can be done through supervision, monitoring, and evaluation to ensure the sustainability of this activity. Junardi, Keliat, and Daulima (2017) confirm in their study that there is a significant relationship between nurses' perceptions of community mental health nursing and stakeholders relevant to the successful implementation of community mental health nursing in the District of Aceh Besar and Kota Banda Aceh.

\section{Expecting to collaborate with relevant government institutions}

Collaboration between mental health nurses, other medical staff, and individuals with mental illness aims to provide support shown by mutual respect and trust. Besides, community mental health nurses are a source of support for inspiration and education (Mancini, Hardiman, \& Lawson, 2005).

Orchard, Curran, and Kabener (2005) state that interdisciplinary collaboration is a partnership between a team of health professionals and clients with a participatory, collaborative, and coordinated approach to make joint decisions about health. Besides, while building community mental health services, Widowati (2018) emphasizes the importance of the role of various regional stakeholders, from the governor who makes make the policy to the village head who executes it through the village head of Desa Siaga Sehat Jiwa (Healthy Soul Alert Village). The responsibility of the health agency includes budget planning, providing medicines, conducting training led by psychiatrists and psychologists and social workers from mental hospitals and mental health nurses.

The performance of community mental health nurses (CMHN) involves families, mental health figures, community leaders, and religious leaders. Sari and Fina (2017) support family involvement in the performance of community mental health nurses, claiming that there is a significant relationship between family support and prevention of relapse in schizophrenic patients ( $\mathrm{p}$-value 0,000), the relation between family emotional support and relapse prevention in schizophrenic patients (p-value 0.0005), relationship between information support from family and relapse prevention in schizophrenic patients (p-value 0.002), relationship between family instrumental support and schizophrenic prevention ( $p$-value 0000), and relationship between family assessment support and schizophrenia (p-value 0.014).

Farkhah, Suryani, and Hernawaty (2017) claim, the most dominant factor in the occurrence of a patient's relapse is the caregiver's quality of life. Therefore, nurses have active roles in improving the quality of caregivers and emphasizing the importance of a caregiver support group.

\section{Being more grateful for caring for people with mental illness}

Being grateful means realizing everything 
we have as God's blessings (Yusuf, Nihayati, Iswari, and Okviasanti, 2016). This is a feeling of being fascinated, grateful, and appreciating life (Emmons \& Shelton, 2005). Also, Watkins, Woodward, Stone, and Kolts (2003) claim that it shows individual characteristics that are full of emotions, respect for others, and simple things.

According to Listiyandini et al. (2015), an individual has emotional and interpersonal privileges of being grateful. They can improve coping skills, whether they realize it or not, by seeing at and feeling sufferings as something positive. Besides, McCullough, Tsang, and Emmons (2004) claim that grateful people have a positive coping mechanism, which can be useful in dealing with life's difficulties, seeking support, interpreting experiences from other angles, and solving problems.

Harbaugh and Vasey (2014) elaborate that the practice of gratitude can reduce symptoms of depression and stress in the workplace. This is supported by Ningrum (2016), who states that the practice of gratitude is beneficial to reduce the stress level of employees.

\section{Conclusion}

Based on the study results and discussion about the life experience of the person in charge of the mental health program for people with mental illness who are in the recovery process, the conclusion is that there are five themes and three sub-themes which emerged as new insights. Being the person in charge of the mental health program is a difficult task; nurses are often embarrassed due to lack of knowledge, and various obstacles in caring for people with mental illness recovery. However, they hold on to their expectations and are consistently grateful that the program can run until these days.

The researcher proposes five suggestions: the first is for the person in charge of the mental health program: to sharpen their knowledge and attend mental health training, collaborate with various stakeholders to deal with people with mental illness during recovery, and be grateful for their job. The second is for patients: to consult to community health center regularly, take medicines, and be active at home, then for their families, to support the patient to take drugs daily, take good care of them, and motivate them to do activities at home or in the community.

The third is for formal institutions such as community health center, hospitals, health services, social services, TRC, and the government. The researcher suggests that community health center provides more human resources, preferably male to help handle people with acute mental illness, reduces the workload of the person in charge of the mental health program, provides SOP about people with mental illness handling, and provides a place and time for medication and consultation for people with mental illness. Moreover, it is also suggested that hospitals cooperate better in terms of evacuation, referrals, and dealing with people with acute mental illness, providing communication channels about patients from hospitals to all parties at community health center to checkup patients.

The suggestion is that health institutions and the government make a Bachelor's degree or competence in mental health as a minimum requirement for nurses in charge of mental health programs. Moreover, they are expected to conduct training on how to be grateful and about mental health for nurses, community leaders, religious leaders, and the community. The fourth suggestion is for the community and community leaders such as environmental, neighborhood and regency cadres, together with religious leaders to enhance cooperation in handling people with mental illnesses and removing the negative stigma toward them.

The fifth suggestion is for the development of Nursing Studies so that students understand the concept of community mental health nurses and people with mental illness recovery so that they can improve their practices in their community. Finally, the sixth suggestion is for further research; to conduct a comprehensive study on the knowledge of community mental health nurses about people with mental illness recovery, barriers, and success factors in the improvement of people with mental illness, and the importance of being grateful. 
Habsyah S Agustina: Nurses' Life Experiences as Persons In Charge of Mental Health Programs

\section{References}

Abdulmalik, J., Kola, L., \& Gureje, O. (2016). Mental health system governance in Nigeria: Challenges, opportunities, and strategies for improvement. Global Mental Health, 3(9).

Bangun, S.R., \& Soewadi, H. (2014). Pengaruh pelatihan kesehatan jiwa pada tenaga kesehatan terhadap pengetahuan dan kolaborasi pelayanan kesehatan jiwa di Puskesmas Kota Yogyakarta (The effect of mental health training on health workers on knowledge and collaboration of mental health services at Puskesmas Kota Yogyakarta). (Doctoral Dissertation, Universitas Gadjah Mada). Electronic Theses \& Disertations (ETD) Gajah Mada University. Diakses di: http://etd.repository. ugm.ac.id/index.php?mod=penelitian_detail $\& \mathrm{sub}=$ PenelitianDetail\&act $=$ view \& $\mathbf{t y p}=\mathrm{htm}$ 1\&buku id=69213 pada tanggal 24 Juli 2018 pada $\mathrm{Pk} \overline{\mathrm{l}}$. 17.27.

Carayon, P., \& Gurses, A.P. (2008). Nursing workload and patient safety - a human factors engineering perspective.

Duffield, C., \& O'Brien-Pallas, L. (2003). The causes and consequences of nursing shortages: A helicopter view of the research. Australian Health Review, 26(1), 186-193.

Edwards, D., Burnard, P., Coyle, D., Fothergill, A., \& Hanniga, B. (2000). Stress and burnout in community mental health nursing: A review of the literature. Journal of Psychiatric and Mental Health Nursing, 7, 7-14.

Emmons, R.A., \& Shelton, C.M. (2005). Gratitude and the science of positive psychology. Dalam C.R. Synder, \& S.J. Lopez (Eds.). Handbook of positive psychology (h. 459-471). New York: Oxford University Press.

Farkhah, L., Suryani., \& Hernawaty, T. (2017). Faktor caregiver dan kekambuhan klien skizofrenia. (Caregiver factors and schizophrenia client recurrence). Padjadjaran Nursing Journal, 5(1), DOI: https:/doi. org/10.24198/jkp.v5i1.348.g149.
Gale, J., \& Lucette, S.M. (2011). Community mental health nurses' perspectives of recovery-oriented practice. Journal of psychiatric and mental health nursing, 19(4), 348-353.

Giorgi, A., \& Giorgi, B. (2008). Phenomenology in J.A. Smith (Eds.). Qualitative psychology: A practical guide to research method (pp.26-51). London: Sage publications.

Giorgi, A. (2011). IPA and science: A response to Jonathan Smith. Journal of Phenomenological Psychology, 42, 195-216.

Happell, B. (2008). Determining the effectiveness of mental health services from a consumer perspective: Part 2: Barriers to recovery and principles for evaluation. International Journal of Mental Health Nursing, 17(2), 123-130.

Harbaugh, C.N., \& Vasey, M.W.(2014). When do people benefit from gratitude practice?. The Journal of Positive Psychology, 9(6), 535-546.

Huang, Y.X., Ma, F.W., Shih, H.H., \& Li, F.H. (2008). Roles and functions of community mental health nurses caring for people with schizofrenia in Taiwan. Journal of Clinical Nursing, 17, 3030-3040. Doi: 10.1111/j. 1365-2702.2008.2426.x.

Ignacio, L. (2000). Mental health care in the community. Paper presented in expert course JSPS NCD Seminar in Jakarta, Indonesia, March 13th.

Junardi.,Keliat,B.A.,Daulima,N.H.C.(2017). Analisis faktor - faktor yang berhubungan dengan keberhasilan pelaksanaan kegiatan community mental health nursing di Aceh. (Analysis of factors related to the successful implementation of community mental health nursing activities in Aceh). Idea Nursing Journal, VIII(1). ISSN: 2087-2879, e-ISSN: $2580-2445$.

Lang, T.A., Hodge, M., Olson, V., Romano, P.S., \& Kravitz, R.L. (2004). Nurse-patient ratios: A systematic review on the effects of 
Habsyah S Agustina: Nurses' Life Experiences as Persons In Charge of Mental Health Programs

nurse staffing on patient, nurse employee, and hospital outcomes. Journal of Nursing Administration, 34(7), 326-337.

Levin, B.L., Hennessy, K.D., \& Petrila, J. (2010). Mental health services: A public health perspective (3rd Ed.). New York: Oxford University Press.

Listiyandini, R.A., Nathania, A., Syahniar, D., Sonia, L., \& Nadya, R. (2017). Mengukur rasa syukur: Pengembangan model awal skala bersyukur versi Indonesia. (Measuring gratitude: Development of an initial model of the Indonesian version of the gratitude scale). Jurnal Psikologi Ulayat: Indonesian Journal of Indigenous Psychology, 2(2), 473-496.

Lopez, K.A., \& Willis, D.G. (2004). Descriptive versus interpretive phenomenology: Their contributions to nursing knowledge. Qualitative health research, 14(5), 726-735.

Mancini, M.A., Hardiman, E.R., \& Lawson, H.A. (2005). Making sense of it all: Consumer providers' theories about factors facilitating and impeding recovery from psychiatric disabilities. Psychiatric Rehabilitation Journal, 29(1), 48.

Marchira, C.R. (2011). Integrasi kesehatan jiwa pada pelayanan primer di indonesia: Sebuah tantangan di masa sekarang. (Integration of mental health into primary care in Indonesia: A challenge today). Jurnal Manajemen Pelayanan Kesehatan, 14(3), 120-126.

McCullough, M.E., Tsang, J.A., \& Emmons, R.A. (2004). Gratitude in intermediate affective terrain: Links of grateful moods to individual differences and daily emotional experience. Journal of personality and social psychology, 86(2), 295.

Ningrum, R.F. (2016). Menurunkan stres kerja karyawan dengan pelatihan kebersyukuran. (Reducing employee work stress with gratitude training). Universitas Islam Indonesia.

Orchard, C.A., Curran, V., \& Kabene, S.
(2005). Creating a culture for interdisciplinary collaborative professional practice. Medical Education Online, 10(1), 4387.

Patton, M.Q. (2005). Qualitative research. Encyclopedia of statistics in behavioral science.

Peraturan Menteri Kesehatan Republik Indonesia No. 406/Menkes/SK/VI/2009 Tentang Pedoman Pelayanan Kesehatan Jiwa Komunitas. (Regulation of the Minister of Health of the Republic of Indonesia No. 406 / Menkes / SK / VI / 2009 concerning Guidelines for Community Mental Health Services)

Pinilih, S.S., Astuti, R.T., \& Amin, M.K. (2015). Manajemen kesehatan jiwa berbasis komunitas melalui Pelayanan keperawatan kesehatan jiwa komunitas di Wilayah Dinas Kesehatan Kabupaten Magelang. (Community-based mental health management through community mental health nursing services in the District Health Office of Magelang District). The 2nd University Research Coloquium 2015. ISSN 2407-9189.

Polit, D.F., \& Beck, C.L (2005) Essentials of nursing research: Methods, appraisal, and utilization (6th Ed.). Lippincott Williams \& Wilkins, Philadelphia.

Polit, D.F., \& Beck, C.L. (2008). Nursing research: Generating and Assessing Evidence for Nursing Practice (8th Ed.). Lippincott Williams \& Wilkins.

Polit, D.F., \& Beck, C.L. (2010). Nursing research: Principle and methods (7th Ed.). Philadephia: Lippincott Williams\& Wilkins.

Russell, L. (2010). Mental health care services in primary care tackling the issues in the context of health care reform. Center for American Progress.

Sari, H., \& Fina, F. (2017). Dukungan keluarga dalam mencegah kekambuhan pasien skizofrenia di Poliklinik Rawat Jalan RSJ Aceh. (Family support in preventing recurrence of schizophrenic patients at the 
Habsyah S Agustina: Nurses' Life Experiences as Persons In Charge of Mental Health Programs

Outpatient Polyclinic of RSJ Aceh). Idea Nursing Journal, 2(3), ISSN : 2087-2879.

Streubert, H., \& Carpenter, D. (2007). Qualitative research in nursing: Advancing the humanistic imperative (4th Ed.). Lipincott Williams\& Wilkins, Philadelphia.

Suryani. (2012). Chaotic soul-messy heart: The phenomenon of experiencing auditory hallucinations. Tesis. QUT Queensland University of Technology School of Nursing and Midwifery.

Suryani. (2013). Orasi Ilmiah Fakultas Ilmu Keperawatan Universitas Padjadjaran. Tema: Trend \& Issue Gangguan Jiwa, Pemulihan Pasien Skizofrenia. (Scientific Oration of the Faculty of Nursing, Padjadjaran University. Theme: Trends \& Issues of Mental Disorders, Recovery of Schizophrenia Patients)

Suryani, S., Welch, A., \& Cox, L. (2016). The Application of Colaiizi's Method in Conducting Research Across Two Language. Malaysian Journal of Psychiatry, 25(1), 1928.
Watkins, P.C., Woodward, K., Stone, T., \& Kolts, R.L. (2003). Gratitude and happiness: Development of a measure of gratitude, and relationships with subjective wellbeing. Social Behavior and Personality: an international journal, 31(5), 431-451.

Widowati, A. (2017). Pemberdayaan masyarakat dalam membangun kesehatan jiwa komunitas (studi kasus di Kabupaten Magelang). (Community empowerment in building community mental health (case study in Magelang District)). Jurnal Impuls, 3(1), 219-224, ISSN 2442-7039.

World Health Organization. (2005). Mental health atlas 2005. Diakses dari: http://www. who.int/mental health/evidence/mhatlas05/ en/ pada tanggal 17/1/2018 pada Pkl. 15.00 WIB.

Yusuf, A., Nihayati, H.E., Iswari, M.F., \& Okviasanti, F. (2017). Kebutuhan spiritual konsep dan aplikasi dalam asuhan keperawatan. (Spiritual needs concepts and applications in nursing care). Jakarta: Mitra Wacana Media. 